\title{
EFEK TEKANAN UDARA TERHADAP FISIOLOGI TUBUH ATLET
}

Oleh: Ali Satya Graha

Dosen Jukusan Pendidikan Kesehatan dan Rekreasi FIK UNY

\section{Abstrak}

Moderenisasi semakin menjanjikan untuk
perkembangan para atlet dan prestasi tanpa met yang mencapai kesuksesan efek dari aktivitas olahragerdulikan kondisi fisik dan harus siap bertandinga tersebut, sehingga mereka bagaima siap bertanding dalam kondisi dan situasi bagaimanapun baik dalam cuaca maupun kondisi alam yang berubah-ubah. Atlet terkadang harus bertanding di tempat yang lebih tinggi ataupun di tempat yang rendah dibanding daratan. Oleh karena itu penting bagi atlet, pelatih, dan penyelenggara pertandingan untuk mengetahui efek fisiologi dari berbagai macam stres lingkungan pada atlet yang ákan bertanding. Terutama di sini pada daerah ketinggian yang berbeda, misalkan pada sekelompok atlet tidak mudah dengan gerak cepat bertanding di kota yang lebih tinggi tempatnya dari tempat di mana atlet-atlet biasa berlatih.

Jadi diperlukan penyesuaian atau adaptasi tubuh terlebih dahulu sebelum bertanding. Ini disebabkan adanya perbedaan tekanan udara atau tekanan $\mathrm{O} 2$ di tempat dengan ketinggian yang berbeda. Sehingga kemampuan kerja otot juga menjadi berubah dan tidak menimbulkan persoalan hipoksia pada fisiologi tubuh atlet saat bertanding di tempat tinggi.

\section{Kata kunci: tekanan udara}

Moderenisasi semakin menjanjikan untuk perkembangan para atlet yang mencapai kesuksesan dan prestasi tanpa memperdulikan

MEDIKORA Vol. V, No 1, April 2009: 1-11 
kondisi fisik dan efek dari aktivitas olahraga tersebut, sehingga mereka harus siap bertanding dalam kondisi dan situasi bagaimanapun baik dalam cuaca maupun kondisi alam yang berubah-ubah. Atlet terkadang harus bertanding di tempat yang lebih tinggi ataupun di tempat yang rendah dibanding daratan. Oleh karena itu penting bagi atlet, pelatih dan penyelenggara pertandingan untuk mengetahui efek fisiologi dari berbagai macam stres lingkungan pada atlet yang akan bertanding. Terutama disini pada daerah ketinggian yang berbeda, misalkan pada sekelompok atlet adalah tidak mudah dengan gerak cepat bertanding di tempat yang lebih tinggi tempatnya dari tempat dimana atlet-atlet biasa berlatih (Foss, 1998). Jadi diperlukan penyesuaian atau adaptasi tubuh terlebih dahulu sebelum bertanding. Ini disebabkan adanya perbedaan tekanan udara atau tekanan O2 di tempat dengan ketinggian yang berbeda Penurunan tekanan barometer ini merupakan dasar penyebab dari semua persoalan hipoksia pada fisiologi manusia di tempat tinggi., Sehingga kemampuan kerja otot juga menjadi berubah.

\section{Tekanan Barometer di Berbagai Ketinggian Tempat}

Pada ketinggian permukaan laut tekanan barometer adalah $760 \mathrm{~mm} \mathrm{Hg}$, sedangkan pada ketinggian 10.000 kaki hanya 523 $\mathrm{mm} \mathrm{Hg}$, dan pada 50.000 kaki adalah $87 \mathrm{~mm} \mathrm{Hg}$. Penurunan tekanan barometer ini merupakan dasar penyebab dari semua persoalan hipoksia pada fisiologi manusia di tempat tinggi, karena 
seiring dengan penurunan tekanan barometer akan terjadi juga penurunan tekanan oksigen parsial yang sebanding, sehingga tekanan oksigen selalu tepat yaitu sedikit lebih rendah dari 21 persen dibanding tekanan barometer total pada ketinggian permukaan laut sekitar $159 \mathrm{~mm} \mathrm{Hg}$, tetapi pada ketinggian 50.000 kaki hanya $18 \mathrm{~mm} \mathrm{Hg.} \mathrm{(Guyton} \mathrm{and} \mathrm{Hall,} \mathrm{1996)}$

\section{PO2 Alveolus pada berbagai Ketinggian}

Kolom kelima pada tabel 1 memperlihatkan PO2 di alveoli pada berbagai ketinggian bila seseorang menghirup udara dalam keadaan teraklimatisasi dan tidak teraklimatisasi. Pada ketinggian permukaan laut, PO2 Alveolus adalah 104 mm Hg; pada ketinggian 20.000 kaki, tekanan ini menurun sampai sekitar $40 \mathrm{~mm} \mathrm{Hg}$ pada orang yang tidak teraklimatisasi, tetapi hanya $53 \mathrm{~mm} \mathrm{Hg}$ pada orang beraklimatisasi. Perbedaan dari kedua hal ini adalah bahwa ventilasi alveolus meningkat sekitar lima kali lipat pada orang yang berklimatisasi.

MEDIKORA Vol. V, No 1, April 2009: 1-11 
Tabel 1. Pengaruh Paparan Akut Tekanan Atmosfer yang Rendah terhadap Kadar Gas Alveolus dan Kejenuhan Oksigen Arteri.

\begin{tabular}{|c|c|c|c|c|c|c|c|c|}
\hline & I & $\sqrt{3 x+2}$ & & $\begin{array}{l}\text { Menghir } \\
\text { up udara }\end{array}$ & & & $\begin{array}{c}\text { Menghir } \\
\text { up } \\
\text { o2 } \\
\text { murni }\end{array}$ & \\
\hline $\begin{array}{l}\text { Ketin } \\
\text { ggian } \\
\text { (Kaki) }\end{array}$ & $\begin{array}{l}\text { Tekanan } \\
\text { Baromet } \\
\text { er } \\
\text { (mm Hg) }\end{array}$ & $\begin{array}{l}\text { PO2 } \\
\text { dlm } \\
\text { uda } \\
\text { ra } \\
\text { (m } \\
\text { m } \\
\mathrm{Hg})\end{array}$ & $\begin{array}{l}\text { Pco2 } \\
\text { dlm } \\
\text { alveo1 } \\
\text { i } \\
\text { (mm } \\
\mathrm{Hg})\end{array}$ & $\begin{array}{l}\text { Po2 dlm } \\
\text { alveoli(m } \\
\text { m Hg) }\end{array}$ & $\begin{array}{l}\text { Kejen } \\
\text { u } \\
\text { han } \\
\text { O2 } \\
\text { Arteri } \\
(\%)\end{array}$ & $\begin{array}{l}\text { Pco } \\
2 \\
\text { dlm } \\
\text { Alve } \\
\text { oli( } \\
\mathrm{mm} \\
\mathrm{Hg})\end{array}$ & $\begin{array}{l}\text { Po2 dlm } \\
\text { Alveoli( } \\
\text { mm Hg) }\end{array}$ & $\begin{array}{l}\text { Kejen } \\
\text { uhan } \\
\text { O2 } \\
\text { Arteri } \\
\text { (mm } \\
\text { Hg) }\end{array}$ \\
\hline 0 & 760 & 159 & $40(40)$ & $104(104)$ & 97(97) & 40 & 673 & 100 \\
\hline $\begin{array}{l}10.00 \\
0\end{array}$ & 523 & 110 & $36(23)$ & $67(77)$ & $90(92)$ & 40 & 436 & 100 \\
\hline $\begin{array}{l}20.00 \\
0\end{array}$ & 349 & 73 & $24(5)$ & $40(53)$ & $73(85)$ & 40 & 262 & 100 \\
\hline $\begin{array}{l}30.00 \\
0\end{array}$ & 226 & 47 & $24(7)$ & $18(30)$ & $24(38)$ & 40 & 139 & 99 \\
\hline $\begin{array}{l}40.00 \\
0\end{array}$ & 141 & 29 & & $2 \pi$ & & 36 & 58 & 84 \\
\hline $\begin{array}{l}50.00 \\
0\end{array}$ & 87 & 18 & & & & 24 & 18 & 15 \\
\hline
\end{tabular}

CO2 dan Uap Air Menurunkan Oksigen Alveolus

Di tempat yang tinggi pun karbondioksida tetap diekskresi dari darah paru ke Alveoli. Demikian pula, air menguap kedalam udara inspirasi dari permukaan alat pernapasan. Oleh sebab itu, kedua gas ini akan mengencerkan oksigen dalam alveoli, sehingga menurunkan kadar oksigen.

Tekanan uap air dalam alveoli tetap $47 \mathrm{~mm} \mathrm{Hg}$ selama suhu tubuh normal, tidak bergantung pada ketinggian. Lain halnya dengan karbondioksida, selama berada ditempat yang sangat tinggi, 
PCO2 alveolus turun dari $40 \mathrm{~mm} \mathrm{Hg}$ (nilai dipermukaan laut) kenilai yang lebih rendah. Pada seseorang yang teraklimatisasi, yang ventilasinya meningkat sampai lima kali lipat, terjadi penuruna sekitar $7 \mathrm{~mm} \mathrm{Hg}$ akibat peningkatan pernapasan.

Sekarang mari kita lihat bagaimana tekanan kedua gas tersebut mempengaruhi oksigen alveolus. Sebagai contoh, katakanlah bahwa tekanan barometer turun, menjadi $253 \mathrm{~mm} \mathrm{Hg}$, yang nilainya diukur dari puncak gunung Everest pada ketinggian 29.028 kaki. Empat puluh tujuh milimeter air raksa dari ini tertunya uap air, dan sisanya hanya 206 mm Hg untuk seluruh gas-gas lain. Pada seseorang yang teraklimatisasi, $7 \mathrm{~mm}$ dari 206 $\mathrm{mm} \mathrm{Hg}$ tentunya merupakan karbon dioksida, dan sisanya hanya $109 \mathrm{~mm} \mathrm{Hg}$. Jika tidak ada oksigen yang digunakan oleh tubuh, seperlima dari $199 \mathrm{~mm} \mathrm{Hg}$ ini akan berupa oksigen dan empatperlimanya merupakan nitrogen; atau PO2 dalam alveoli akan menjadi $40 \mathrm{~mm} \mathrm{Hg}$. Sebagian dari oksigen alveoli yang tersisa ini akan di absorsi kedalam darah, menghasilkan tekanan oksigen sekitar $35 \mathrm{~mm} \mathrm{Hg}$ di dalam alveoli. Karena itu, pada puncak Gunung Everest, hanya orang-orang yang memiliki aklimatisasi terbaik yang dapat bertahan hidup saat menghirup udara. Tetapi pengaruh ini sangat berbeda bila seseorang menghirup oksigen murni.

MEDIKORA Vol. V, No 1, April 2009: 1-11 
Efek Menghirup Oksigen Murni terhadap PO2 Alveolus pada Perbagai Ketinggian

Bila seseorang menghirup oksigen murni sebagai pengganti udara, Imaka sebagian besar ruangan dalam alveoli yang sebelumnya terisi oleh nitrogen sekarang menjadi terisi oleh oksigen. Karena itu, pada ketinggian 30.000 kaki penerbang dapat mempunyai PO2 sebesar $139 \mathrm{~mm} \mathrm{Hg}$, bukan $18 \mathrm{~mm} \mathrm{Hg}$ seperti ketika menghirup udara biasa.

Kejenuhan arteri pada ketinggian 47.000 kaki bila seseorang menghirup oksigen kira-kira 50 persen, dan ini sama dengan kejenuhan oksigen arteri pada ketinggian 23.000 kaki bila seseorang menghirup udara. Selain itu, karena seseorang yang tidak teraklimatisasi dapat tetap sadar sampai kejenuhan oksigen arteri turun hingga 50 persen, dalam waktu yang singkat, plafon bagi penerbang yang mengemudikan pesawat tanpa alat pengukur tekanan bila menghirup udara kira-kira adalah 23.000 kaki, sedangkan bila menghirup oksigen murni kira-kira 47.000 kaki, asalkan alat pensuplai oksigen berjalan dengan baik

\section{Efek Tekanan 02 yang Rendah Terhadap Tubuh Atlet}

Penurunan tekanan $\mathrm{O} 2$ parsial yang sebanding dengan penurunan tekanan barometer ini, merupakan dasar dari penyebab semua persoalan hipoksia pada fisiologi atlet saat akan melakukan pertandingan di tempat yang tinggi. Pada hipoksia jaringan tubuh mengalami kekurangan $\mathrm{O} 2$ dalam jumlah dan konsentrasi molekulnya (Dirkes AU, 1995). 
Beberapa efek akut penting dari hipoksia yang harus diketahui oleh atlet dan pelatih, seperti pada tempat yang memiliki ketinggian mulai dari 12.000 kaki ialah mengantuk, malas, kelelahan mental dan otot-otot, kadang-kadang sakit kepala, mual, dan euforia. Semua gejala-gejala ini berkembang progresif menjadi tahap kedutan (twiching) atau kejang diatas ketinggian 18.000 kaki dan akirnya, di atas ketinggian di atas 23.000 kaki berakir dengan koma pada atlet yang belum mengalami aklimatisasi (Foss dan Ketenyian, 1998).

Salah satu efek utama dari hipoksia ialah menurunya kecakapan mental, yang akan menurunkan kemampuan dalam pengambilan keputusan, mengingat, dan dalam melakukan gerakan motorik yang berlainan. Sebagai contoh, jika seorang penerbang yang belum mengalami aklimatisasi berada pada ketinggian 15.000 kaki selama satu jam, kemampuan mental biasanya turun menjadi 50 persen normal, dan setelah 18 jam turun menjadi 20 persen.

\section{Aklimatisasi Tehadap PO2 yang Rendah pada Atlet}

Atlet yang tinggal ditempat tinggi selama beberapa hari, minggu, tahun, menjadi semakin teraklimatisasi terhadap PO2 yang rendah, sehingga efek buruknya terhadap tubuh makin lama makin berkurang, dan memungkinkan atlet tersebut untuk bekerja lebih berat tanpa mengalami efek hipoksia atau untuk naik ketempat yang lebih tinggi (Guyton and Hall, 1996, Ganong F.W., 1999)

MEDIKORA Vol. V, No 1, April 2009: 1-11 
Prinsip-prinsip utama yang terjadi pada aklimatisasi ialah:

1. Peningkatan ventilasi paru yang cukup besar.

2. Sel darah merah bertambah banyak.

3. Kapassitas difusi paru meningkat.

4. Vaskularisasi jaringan meningkat.

5. Kemampuan sel dalam menggunakan oksigen menigkat sekalipun PO2 rendah. (Ganong F.W., 1999)

\section{Aklimatisasi Alami Pada Alet yang Tinggal di Tempat Tinggi.}

Banyak atlet pendaki gunung yang tinggal di pengunungan Andes dan Himalaya yang berada pada ketinggian 13.000 kaki karena mereka bangga akan prestasi dan kebanggaan menaklukan gunung tersebut. Sehingga ada beberapa atlet tersebut menjadi penduduk dan bermukim di ketinggian itu dan tinggal di sana sepanjang hidupnya. Dalam semua aspek aklimatisasi, atlet ini lebih superior dibandingkan dengan penduduk dengan tempat rendah dengan aklimatisasi terbaik. Atlet yang terlahir disana akan menjadi superior dengan aklimatisasi penyesuaian dalam berbagai hal. Beberapa ciri-ciri atlet yang terlahir di tempat ketinggian antara lain: ukuran dadanya sangat besar, sedangkan ukuran tubuhnya sedikit lebih kecil, sehingga rasio kapasitas ventilasi terhadap masa tubuh menjadi besar. Selain itu, jantungnya, terutama jantung kanan jauh lebih besar dari pada orang yang tinggal ditempat rendah, jantung kanan yang besar itu menghasilkan tekanan yang tinggi dalam arteri pulmonalis sehingga dapat mendorong darah melalui kapiler paru yang telah 
sangat melebar. Pengangkutan oksigen oleh darah kejaringan juga jauh lebih mudah pada orang-orang diatas. (Guyton and Hall, 1996).

\section{Kapasitas Kerja Tubuh pada Saat Berlatih atau Bertanding di Tempat Tinggi pada Efek Aklimatisasi}

Atlet pada saat penyesuaian berlatih atau memulai bertanding di tempat tinggi akan mengalami berbagai hal. Seperti depresi mental yang disebabkan oleh hipoksia, seperti yang telah diuraikan diatas, kapasitas kerja semua otot juga ternyata sangat menurun pada hipoksia. Bukan hanya otot rangka tetapi otot jantung juga dipengaruhi, sehingga curah jantung maksimal juga berkurang. Secara umum, dapat dikatakan bahwa kapasitas kerja berkurang sebanding dengan ambilan oksigen maksimal yang dapat dicapai oleh tubuh.

Untuk memberikan gambaran tentang pentingnya aklimatisasi terhadap kapasitas kerja tubuh saat berlatih ataupun bertanding perlu memperrhatikan hal dibawah ini: Kapasitas kerja dihitung dalam nilai persetase normal bagi atlet-atlet yang tidak berklimatisasi dan beraklimatisasi pada ketinggian 17.000 kaki, seperti yang dicantumkan berikut ini: (Guyton and Hall, 1996)

\section{Persen}

Tidak beraklimatisasi 50

Aklimatisasi selama dua bulan 68

Penduduk yang tinggal di ketinggian $13.200-17.000$ 87

MEDIKORA Vol. V, No 1, April 2009: 1-11 
Jadi, penduduk yang beraklimatisasi secara alami, seharihari dapat bekerja di tempat tinggi hampir sama dengan orang normal yang tinggal di tempat setinggi permukaan laut, tetapi pendudừk dari tempat rendah yang kemudian beraklimatisasi baik hampir tidak pernah mencapai hasil sebaik itu.

\section{KESIMPULAN}

Atlet dan pelatih saat akan berlatih ataupun bertanding di tempat tinggi perlu memperhatikan tekanan udara ditempat tersebut untuk menyesuaikan aklimatisasi pada tempat tersebut. Perubahan aklimatisasi ini akan mempengaruhi terhadap tubuh atlet seperti pada tekanan oksigen (O2) berbanding lurus dengan tekanan udara (barometer) namun berbanding terbalik dengan ketinggian. Apabila kondisi tekanan $\mathrm{O} 2$ yang rendah akan menimbulkan hipoksia. Ada beberapa efek akut dari hipoksia :

1. Mengantuk, malas, kelelahan mental dan otot-otot

2. Kadang-kadang sakit kepala, mual, dan euforia

3. Kedutan (twiching) atau kejang

4. Koma

Aklimatisasi ada 2 macam :

1. Aklimatisasi biasa :

Tinggal di suatu tempat (ketinggian) selama beberapa hari, minggu, tahun sehingga efek buruk PO2 yang rendah terhadap tubuh semakin berkurang.

2. Aklimatisasi alami :

Proses aklimatisasi yang dimulai sejak bayi. 
Tujuan dari makalah ini adalah untuk menambah pengetahuan bagi atlet dan pelatih dapat dijadikan sumber referensi dalam mempelajari penampilan atlet ketika latihan atau bertandingtpada tempat ketinggian yang berbeda.

\section{DAFTAR PUSTAKA}

Direktorat Kesehatan TNI AU 1995. Dasar-Dasar Ilmu Kesehatan Penerbangan. Jakarta : Direktorat Kesehatan TNI AU.

Foss M.L., Ketenyian S.J. 1998. Fox's Physiological basis of Exercise and Sport $6^{\text {th }}$ edition. McGraw Hill Company.

Ganong F.W., 1999, Buku Ajar Fisiologi Kedokteran, Edisi 17, Penerbit Buku Kedokteran EGC, Jakarta

Guyton AC, Hall JE. 1996, Texbook of medical physiology. 9th ed. Philadelphia: WB Saunders Company; . 